\title{
Zakat dan Pemberdayaan Ekonomi Mustahik: Studi Pada Lembaga Amil Zakat, Infak Dan Shodaqoh Muhammadiyah (LAZISMU) Kabupaten Malang
}

\author{
Rahmad Hakim ${ }^{1)}$, Muslikhati ${ }^{2)}$, Mochamad Novi Rifa'i ${ }^{3)}$ \\ 1,2,3 Program Studi Ekonomi Syariah, Universitas Muhammadiyah Malang \\ *Email korespondensi: rahmadhakim@umm.ac.id
}

\begin{abstract}
This study aims to determine the Zakah utilization on the development of economic of zakah recipients Amil Zakat, Infak and Shodaqoh Muhammadiyah Institutions (LAZISMU) Malang Regency. To achieve the objectives of this research, this research was a quantitative descriptive approach which a research approach that emphasizes the aspect of measurement objectively of social phenomena and produces findings that can be obtained using statistical procedures or other ways of quantification (measurement). Data collection methods used are various data collection methods, including: interview and documentation methods, and data analysis used content analysis. Based on the result found that found that the utilization of zakat funds at LAZISMU Malang Regency was able to increase the economic empowerment of mustahik based on several indicators: the usefulness of a program, accuracy and objectivity, the scope of a program, cost effectiveness, timeliness, and accountability. While in the aspect of timeliness of reporting, the financial reporting of zakat funds is seems not up to date.
\end{abstract}

Keywords: Zakah, Zakah Recipients, Economic Empowerment, Zakah Utilization.

Saran sitasi: Hakim, R., Muslikhati., \& Rifa'i, M. N. (2020). Zakat dan Pemberdayaan Ekonomi Mustahik: Studi Pada Lembaga Amil Zakat, Infak Dan Shodaqoh Muhammadiyah (LAZISMU) Kabupaten Malang. Jurnal Ilmiah Ekonomi Islam, 6(03), 469-477. doi: http://dx.doi.org/10.29040/jiei.v6i3.1356

DOI: http://dx.doi.org/10.29040/jiei.v6i3.1356

\section{PENDAHULUAN}

Kemiskinan seringkali dianggap sebagai bagian tak terpisahkan dalam kehidupan. Beberapa penyebab kemiskinan, meliputi pertama, kemiskinan natural, seperti alam yang tandus, kering dan sebagainya. Kedua, kemiskinan kultural, karena perilaku malas, tidak mau bekerja dan mudah menyerah. Ketiga, kemiskinan struktural, karena berbagai peraturan dan kebijakan pemerintah yang kurang berpihak pada masyarakat miskin, kebijakan dalam bidang ekonomi, pendidikan dan sebagainya. Dalam perspektif ajaran agama Islam, muara kemiskinan adalah perilaku masyarakat yang tidak mencerminkan sebagai orang yang beriman, bertakwa dan beramal saleh (Hafidhuddin, 2007).

Penanggulangan kemiskinan dapat melalui beberapa cara. Salah satunya adalah melalui optimalisasi ZIS. ZIS (zakat, infak, sedekah) merupakan salah satu institusi yang diajarkan Islam untuk menanggulangi kemiskinan atau meminimalisir masalah kemiskinan (Hafidhuddin, 2007), dengan mengurangi jumlah dan persentase keluarga miskin, serta mengurangi tingkat kemiskinan. Zakat merupakan suatu tindakan penyerahan harta kekayaan dari golongan kaya kepada golongan miskin. mendistribusikan kekayaan berarti juga ikut mendistribusikan sumber-sumber ekonomi. Tindakan ini tentu akan mengakibatkan perubahan tertentu yang bersifat ekonomis, contohnya seperti, seseorang yang menerima zakat bisa menggunakannya untuk kebutuhan konsumsi atau produksi. Dengan demikian, zakat meskipun pada dasarnya merupakan ibadah kepada Allah namun juga memiliki dimensi ekonomi (Hakim, 2019).

Sehubungan dengan hal di atas, Rahardjo dalam Muhammad menyatakan bahwa menggunakan pendekatan ekonomi, zakat bisa berkembang menjadi konsep kemasyarakatan (muamalah), yaitu konsep tentang bagaimana cara manusia melaksanakan kehidupan bermasyarakat, termasuk di dalamnya dalam bentuk ekonomi (Muhammad, 2002). Tujuan zakat tidak sekedar menyantuni orang miskin secara 


\section{Jurnal Ilmiah Ekonomi Islam, 6(03), 2020, 470}

konsumtif, tetapi mempunyai tujuan yang lebih permanen yaitu mengentaskan kemiskinan (Qadir, 2001) dan menanggulangi kesenjangan ekonomi (Kholiila, 2016).

Sehubungan dengan hal itu, maka zakat dapat berfungsi sebagai salah satu sumber dana sosialekonomi bagi umat Islam (Hakim, 2020). Artinya pendayagunaan zakat yang dikelola oleh Lembaga Zakat tidak hanya terbatas pada kegiatan-kegiatan tertentu saja yang berdasarkan pada orientasi konvensional (kegiatan konsumtif), tetapi dapat pula dimanfaatkan untuk kegiatan-kegiatan ekonomi umat seperti tujuan pendistribusian dan pendayagunaan zakat yakni pengentasan kemiskinan dan pengangguran dengan memberikan zakat produktif kepada mereka yang memerlukan sebagai modal usaha (Pratama, 2015).

Zakat yang diberikan kepada mustahik akan berperan sebagai pendukung dalam peningkatan ekonomi apabila di salurkan pada kegiatan produktif. Pendayagunaan zakat produktif sesungguhnya mempunyai konsep perencanaan dan pelaksanaan yang cermat seperti mengkaji penyebab kemiskinan, ketidakadaan modal kerja, dan kekurangan lapangan kerja, dengan adanya masalah tersebut maka perlu adanya perencanaan yang dapat mengembangkan zakat bersifat produktif (Riyadi, 2014).

Tujuan pengelolaan zakat adalah meningkatnya kesadaran masyarakat dalam penunaian dan dalam pelayanan ibadah zakat, meningkatnya fungsi dan peranan pranata keagamaan dalam upaya mewujudkan kesejahteraan masyarakat dan keadilan sosial, serta meningkatnya hasil guna dan daya gunazakat (Sumadi, 2017).

Di Indonesia, terdapat dua jenis lembaga zakat yang diakui oleh perundang-undangan ada dua, yaitu Badan Amil Zakat (BAZ) dan Lembaga Amil Zakat (LAZ) (Abidah, 2010). Meningkatnya penghimpunan dana zakat tidak lepas dari peran lembaga zakat (Mubarok \& Fanani, 2014; Hakim, 2017). Dengan demikian, penyerahan zakat penting untuk ditunaikan melalui lembaga zakat agar dapat berdayaguna dengan efektif. Pendayagunaan yang efektif ialah pendayagunaan yang sesuai dengan tujuan dan jatuh kepada yang berhak menerima zakat secara tepat (Maghfiroh, 2007). Hal ini disebabkan karena organisasi zakat memiliki peran yang sangat besar dalam menyelesaikan masalah kemiskinan serta menguatkan ekonomi umat (Dzikron, dkk, 2005; Ningrum, 2016; Karimah, 2017; Amsari, 2019).
Pendistribusian zakat kepada para mustahik dapat dalam bentuk konsumtif atau produktif (Hakim, 2018). Zakat secara konsumtif diberikan kepada mustahik yang tidak memiliki kemampuan mengolah dana sehingga akan lebih bijaksana apabila diberikan berupa uang untuk keperluan sehari-hari. Sementara, zakat produktif diberikan kepada mustahik yang cukup mampu untuk mengelola modal yang diberikan. Pemberian dapat berupa uang, peralatan atau hewan ternak dengan tujuan dapat meningkatkan pendapatan para mustahik (Widiastuti, 2016). Dengan demikian, jumlah dana yang didistribusikan harus berbeda-beda sesuai dengan tempat, waktu, jenis usaha, dan sifat penerima zakat. Untuk itu memanfaatkan serta mendayagunakan zakat memerlukan kebijaksanaan dan visi kemaslahatan dari pemerintah selaku amil zakat (Noor, 2003).

Beberapa penelitian telah dilakukan terkait dengan peran zakat yang begitu signifikan terhadap pemberdayaan ekonomi para mustahik zakat (Zakiyah, 2006; Fajar, 2016; Pratama, 2013; Rusli, Hamzah, Syahnur, 2013). Dalam rangka peningkatan ekonomi mustahik, dilakukan beberapa model terkait dengan zakat produktif diantaranya adalah revolving fund, self help groups dan joint business group (Nafiah, 2015; Ningrum, 2016; Widiastuti, 2016). Selain itu, terdapat beberapa indikator terkait dengan pendayagunaan zakat, yaitu ketepatan sasaran program dan pemantauan program, dan indikator sosialisasi program dan tujuan program (Savid, 2017). Selanjuntya, efektifitas dana zakat pada mustahik zakat juga dapat menggunakan metode CIBEST (Sumantri, 2017).

Berdasarkan uraian di atas, penelitan ini bertujuan untuk melakukan penelitian tentang pendayagunaan dana zakat dalam rangka pemberdayaan ekonomi mustahik pada lembaga amil zakat, infak dan shodaqoh muhammadiyah (LAZISMU) Kabupaten Malang. Dalam rangka pemecahan masalah kemiskinan, penelitian ini dilakukan untuk melakukan analisis mendalam terkait pendayagunaan dana zakat yang telah terkumpul guna diberikan kepada mustahik dalam bentuk kegiatan maupun aktivitas pemberdayaan ekonomi. Dengan demikian, diharapkan dari aktivitas yang dilakukan dapat memberikan kontibusi untuk perbaikan maupun langkah-langkah aksi bagi lembaga amil zakat lain untuk pelaksanaan pemberdayaan ekonomi mustahik. 


\section{METODE PENELITIAN}

Penelitian ini menggunakan kualitatif deskriptif, yaitu pendekatan penelitian yang menekankan pada aspek pengukuran secara obyektif terhadap fenomenafenomena sosial dan menghasilkan penemuanpenemuan yang dapat diperoleh dengan menggunakan penjelasan deskriptif atau cara-cara lain (Nazir, 1998). Pelaksanaan penelitian ini akan dilakukan dengan cara ikut serta dalam kegiatan operasional rutin pada harihari kerja di Lembaga Amil Zakat Muhammadiyah (LAZISMU) Kabupaten Malang dan juga melakukan wawancara dengan amil Zakat pada lembaga tersebut.

Dalam penelitian ini, pengumpulan data menggunakan beberapa teknik berikut (Sugiyono, 2003; Raco, 2003): pertama, wawancara, metode ini dilakukan dengan mempersiapkan pertanyaan kepada amil zakat untuk mengetahui program-program pemberdayaan zakat yang diperuntukkan kepada mustahik zakat. Kedua, dokumentasi, metode ini dilakukan dengan cara mengumpulkan data mustahik dan jumlah penyalurannya kepada mustahik oleh Lembaga Amil Zakat, Infak dan Shodaqoh Muhammadiyah (LAZISMU) Kabupaten Malang. Selain itu juga menelusuri dan menelaah buku-buku serta karya ilmiah yang berkaitan dengan pengelolaan dan pendayagunaan zakat produktif guna mencari landasan pemikiran dan pemecahan masalah.

Selanjutnya, teknik analisis data dalam penelitian ini menggunakan analisis data konten (content data analysis) (Bungin, 2003) yaitu analisis data yang diawali dengan menemukan lambang-lambang tertentu, dalam hal ini adalah melakukan inventarisir terhadap teks-teks yang relevan dengan topik penelitian terkait dengan pengelolaan dana zakat, efektifitas sebuah program pendayagunaan, dan pemberdayaan ekonomi mustahik zakat. Selanjutnya dilakukan klasifikasi data berdasarkan simbol efektifitas pendayagunaan zakat dalam dalam hal ini adalah melakukan klasifikasi perihal pendayagunaan dana zakat dalam rangka pemberdayaan ekonomi mustahik pada lembaga amil zakat, infak dan shodaqoh muhammadiyah (LAZISMU) Kabupaten Malang. Dalam penelitian ini, ukuran efekifitas dari sebuah aktivitas atau kegiatan didasarkan pada enam hal penting, yaitu (Handoko, 1991): (a) kegunaan, (b) ketepatan dan obyektifitas, (c) ruang lingkup, (d) efektifitas biaya, (e) ketepatan waktu, (f) akuntabilitas.

\section{HASIL DAN PEMBAHASAN}

\subsection{Hasil penelitian}

Efektifitas merupakan kegiatan-kegiatan yang dilakukan oleh suatu organisasi agar pelaksanaan kegiatan yang dilakukan dalam organisasi tersebut dapat terialisasi sesuai dengan ketentuan-ketentuan yang telah ditetapkan sebelumnya sehingga mencapai hasil yang baik (Witrido, 2010). Ukuran Efekifitas dari sebuah aktivitas atau kegiatan menurut Handoko di dasarkan kepada ada enam hal penting, yaitu (Handoko, 1991): (a) kegunaan, (b) ketepatan dan obyektifitas, (c) ruang lingkup, (d) efektifitas biaya, (e) ketepatan waktu, (f) akuntabilitas.

\section{a. Kegunaan}

Pada LAZISMU Kabupaten Malang, total pendapatan per-bulan rata-rata mencapai sekitar 45 juta. 45 sampai 60 juta. Akan tetapi, pengumpulan menjadi banyak ketika bulan Ramadhan. Perbandingan pemasukan antara dana zakat dan infak pada kisaran prosentase $20-80 \%$ atau $10-90 \%$.

Selanjutnya, kegunaan donasi zakat adalah untuk delapan golongan penerima zakat, meliputi: [1] orangorang fakir, [2] orang-orang miskin, [3] amil zakat, [4] para mu'allaf yang dibujuk hatinya, [5] orang-orang yang terlilit utang, [6] untuk jalan Allah dan [7] untuk mereka yang sedang dalam perjalanan, sebagaimana tertulis dalam QS. At Taubah: 60. Sementara untuk golongan budak tidak diberikan penyaluran dana zakat bagi golongan ini. Guna menarik minat donator, pada LAZISMU Kabupaten Malang terdapat beberapa program-program pendayagunaan zakat, misalnya: program santunan dhuafa' (fakir miskin), beasiswa, santunan kepada da'i (fi sabililillah), santunan kemanusiaan (bencana alam), bedah rumah, ambulance, dan lain sebagainya, yang tujuannya adalah untuk memberdayakan ekonomi masyarakat (Mashur, 2019).

Selain itu terdapat program insidental yang bekerja sama bersama LAZISMU Pusat seperti donasi untuk korban Gempa di Palu, Sulawesi tengah dan juga pembangunan Rumah Sakit dan Sekolah di Palestina dan santunan kepada warga Rohingnya.

\section{b. Ketepatan dan Objektifitas}

Objektifitas pendayagunaan zakat pada LAZISMU Kabupaten Malang didasarkan kepada skala prioritas dimana golongan yang dianggap paling membutuhkan lebih diprioritaskan di bandingkan yang lain. Dimana jenis pendayagunaan digolongkan kepada tiga bagian; pertama, pendayagunaan yang telah terprogram seperti; santunan fakir miskin, 
santunan kepada guru, santunan kepada da'i. kedua, pendayagunaan berdasarkan proposal yang masuk. Semisal Kagiatan KKN dan lain sebagainya. Ketiga, pendayagunaan yang bersifat insidentil dan bersifat segera, seperti santunan kepada dhu'afa atau orang sakit.

Ketepatan dan objektifitas dalam penyaluran bergantung kepada kebutuhan. Dalam penyalurannya, disebabkan LAZISMU Kabupaten Malang melingkupi Kabupaten yang besar, maka penyaluran dilakukan berpindah-pindah dari kecamatan satu ke kecamatan yang lainnya setiap dua bulan sekali. Selanjutnya, penyaluran yang bersifat terprogram (rutin) meliputi bantuan kepada da'i, beasiswa dan kepada fakir miskin. Bantuan beasiswa kepada para siswa diberikan sebesar 100 ribu rupiah kepada 33 siswa dalam satu bulan, berdasarkan survey yang dilakukan oleh Tim LAZISMU. Selain itu, pendayagunaan kepada fakir miskin dalam satu bulan diberikan kepada 25 orang sebesar 75 ribu. Dan selain itu, terdapat penggunaan dana zakat sebesar 2,5\% guna dana kesiapsiagaan bencana, seperti bencana kekeringan dan lain sebagainya (Mashur, 2019).

Pendayagunaan zakat produktif belum dilakukan pada LAZISMU Kabupaten Malang disebabkan kendala pada SDM, misalnya dalam hal ketersediaan personil dan skill dalam pengwasan atau pendampingan bagi golongan yang menerima zakat produktif, sehingga banyak terjadi kegagalan dalam aplikasi zakat produktif ini, dalam beberapa percobaan pendayagunaan, sebagaimana dinyatakan (Mashur, 2019),

Selanjutnya, dalam unsur ketepatan pendayagunaan, di LAZISMU Kabupaten Malang terdapat dana zakat yang bersifat muqoyyad sehingga menjadikan dana zakat menjadi tepat sasaran dan penyalurannya menggunakan lembaga amil zakat, "Iya seperti itu, terus tuntutan dari pimpinan, itu masih banyak, jadi kita ini cepat. Dan juga banyak dana zakat atau shodaqoh yang muqoyyad (terikat) juga. ... Terikat itu (maksudnya) saya zakat untuk ini, saya infaq untuk ini, ..... Dan itu (muqoyyad) program yang enak sebenarnya, kita nggak pusing-pusing ngurusi program untuk manajemen programnya, jadi kita langsung salurkan ke orangnya......".

Ketepatan dalam penyaluran dapat dilihat dengan pembagian jenis dana zakat mejadi dua macam, dana zakat muqoyyad (terikat) dan ghairu muqoyyad (tidak terikat). Maksud dari dana zakat muqoyyad (terikat) adalah ketika donator menyampaikan peruntukan dari dana zakat yang di donasikan kepada tujuan atau keperluan spesifik tertentu, seperti dana zakat diberikan kepada fakir miskin di panti asuhan atau adanya infak diperuntukkan pembelian tanah (Mashur, 2019),

Dengan demikian, fungsi dari LAZISMU adalah sebagai wadah atau alat untuk menyalurkan dana ZIS termasuk wakaf tunai, yang dibayarkan oleh donator (Mashur, 2019). Selanjutnya, dana zakat yang disalurkan kepada mereka yang berhak adalah sebesar delapan puluh persen $(80 \%)$ dari total dana yang terkumpul. Sementara itu, 20\% dana zakat digunakan untuk operasional amil zakat termasuk didalamnya upah (ujrah) amil zakat dan lain-lainnya (Mashur, 2019).

Dalam rangka penyaluran dana yang tepat sasaran dan obejektif, dilakukan survey oleh Tim LAZISMU, dan dalam kondisi tertentu misalkan bantuan terhadap korban bencana, survey dilakukan dengan bekerjasama bersama tim MDMC (Muhammadiyah Disaster Management Center) Muhammadiyah.

\section{c. Efektifitas Biaya}

Penghimpunannya dana zakat pada LAZISMU Kabupaten Malang menggunakan dua metode, yaitu langsung dan tidak langsung. Pengunaan metode langsung adalah dengan amil zakat mendatangi langsung (menjemput) para donator zakat, atau donator yang datang langsung ke kantor layanan LAZISMU Kabupaten Malang. Hal ini berkaitan dengan efektifitas biaya dan fleksibilitas kerja pengelolaan zakat di LAZISMU, sebagaimana dinyatakan oleh informan (Mashur, 2019),

“... jadi ada donator itu yang minta ada dua: penjemputan, ada yang datang di transfer, dan ada kita mengumpulkan, jadi kita juga ada via penjemputan, ada yang sms, saya jemput, sms atau wa kita jemput, kemudian ada yang melalui transfer tapi tetap langsung sms konfirmasi kalau dia transfer, ada juga yang gak mau di jemput jadi datang langsung sendiri kesini, atau lewat kotak-kotak amal, kita menyebarkan kotak infaq hehehe infaq ke ee... bukan masjid. Keluarga. Keluarga, infaq keluarga itu dri rumahrumah kotak di rumah dari kertas itu, infaq untuk kita di rumah-rumah jadi infaq keluarga, ada yang $\mathrm{Rp}$ 1.000 ,- ada yang Rp 2.000,- menyisakan dari uang belanja, yang Rp 500.an tadi, mau yang bersedia dan minta"

Selanjutnya, dalam rangka efektifitas biaya, beberap kegiatan pengumpulan dan penyaluran 


\section{Jurnal Ilmiah Ekonomi Islam, 6(03), 2020, 473}

dilakukan oleh relasi LAZISMU Kabupaten yang berada di Cabang (Pimpinan Cabang Muhammadiyah) di Kabupaten Malang. Sementara LAZISMU menerima laporan terkait dana yang terkumpul dan yang telah disalurkan kepada golongan penerima zakat, hal ini dalam upaya untuk efektifitas biaya dalam pengelolaan zakat, sebagaimana dinyatakan (Mashur, 2019),

"Jadi, seperti yang saya sampaikan tadi, kita memproposionalkan yang dibawah. Jadi ada LAZISMU, temen-temen yang di kecamatan cabangcabang, itu kita suruh bentuk semua, kita suruh buat program, laporannya kesini, uangnya kesini, pengen buat program tentang sarufan, programnya apa, [undefined] juga mendistribusikan. ....Yang dari bawah pun dananya sebagian besar mereka yang mentasarufkan. Jadi semua kita ada pendayagunaan bersama. Kita cuma mengambil $12.5 \%$, tapi tanpa laporan".

\section{d. Ketepatan Waktu}

Di LAZISMU Kabupaten, penyaluran dana zakat selalu tepat waktu. Sebab penyaluran dana zakat langsung disalurkan dalam jangka waktu satu bulan. Berdasarkan kepada tiga pos penyaluran di atas, yaitu pos penyaluran yang ter-program. Berdasarkan permintaan (proposal) dan penyaluran yang bersifat insidentil (Mashur, 2019). Hanya saja, ketepatan waktu dalam laporan keuangan masih belum terlaksana. Dimana, misalkan dana yang telah di donasikan pada bulan Maret, baru bisa didapatkan laporannya dua bulan setelah donasi (yaitu bulan Mei). Hal ini disebabkan permulaan laporan di awal tahun terlambat. Sebagaimana dinyatakan, "Jadi, yang penting kan ada laporan, tapi jangkanya itu dua bulan setelah pembayaran. Tapi yang jelas kan ada kuitansinya ya. Sama ya yang muqayyad sama yang... nggak, sama saja ya dikasih kuitansi." "Kalau masalah laporan ini kan, kita start-nya (mulai) sudah telat. Start laporan yang disini termasuk."

\section{e. Transparasi dan Akuntabilitas}

Akuntabilitas dalam pengelolaan dengan membuat laporan keuangan sesuai dengan menggunakan Standar PSAK 109 namun masih dalam proses (Mashur, 2019). Sementara itu, akuntabilitas kepada para donator dengan memberikan bukti donasi (kwitansi) yang dapat di akses secara online, sekaligus laporan dalam bentuk majalah mata Hati (gratis bagi donator LAZISMU Kabupaten Malang). Sementara laporan kepada menteri keuangan atau BAZNAS adalah diatur oleh LAZISMU Pusat di Jakarta (Mashur, 2019). Dalam rangka akuntabilitas LAZISMU Kabupaten Malang, terdapat beberapa pengawas yang terdiri dari Pengurus Daerah Muhammadiyah (PDM) khususnya majelis ekonomi, Dewan Syariah LAZISMU Kabupaten Malang, LAZISMU Wilayah Muhammadiyah (PWM) Jawa Timur dan auditor internal, sebagaimana dinyatakan (Mashur, 2019),

“... jadi di PDM itu ada tiga belas pimpinan kan ada ketua seketaris bendahara kemudian ada wakilwakil ketua ada wakil ketua yang menbidangi ZIS itu meskipun ini belum di SK kan ya ee job-desk nya masih pokoknya mengawasi aja dan melihat saja karena ini udah masuk apa namanya Lembaga Zakat Nasional itu sudah job-desk-nya sendiri-sendiri ....."

\subsection{Pembahasan}

Zakat menurut istilah merupakan bagian dari harta dengan persyaratan tertentu, yang Allah SWT mewajibkan kepada pemiliknya untuk diserahkan kepada yang berhak menerimannya, dengan persyaratan tertentu pula (Nawawi, 2010). Kaitan antara makna bahasa dan istilah ini berkaitan erat sekali, yaitu bahwa setiap harta yang sudah dikeluarkan zakatnya akan menjadi suci, bersih, baik, berkah, tumbuh dan berkembang. Dalam penggunaannya, selain untuk kekayaan, tumbuh dan suci disifatkan untuk jiwa orang yang menunaikan zakat. Maksudnya, zakat itu akan mensucikan orang yang mengeluarkannya dan menumbuhkan pahalanya (Ridwan, 2005).

Pendayagunaan zakat telah diatur dalam Undangundang No. 23 tahun 2011, yang menjelaskan bahwa zakat dapat didayagunakan untuk usaha produktif dalam rangka penanganan fakir miskin dan peningkatan kualitas umat. Selanjutnya, dalam rangka pendayagunaan zakat untuk usaha produktif dilakukan apabila kebutuhan dasar mustahik telah terpenuhi.

Pendayagunaan zakat merupakan segala sesuatu yang berkaitan dengan upaya pemerintah dalam memanfaatkan atau mengelola hasil pengumpulan zakat untuk didistribusikan kepada mustahik dengan berpedoman pada syariah, tepat guna, serta pemanfaatan yang efektif melalui pola pendistribusian yang bersifat produktif dan memiliki manfaat sesuai dengan tujuan ekonomis dari zakat itu sendiri (Permono, 1992). Sementara itu, pendayagunaan dana zakat mempunyai beberapa prosedur penting berikut: pertama, melakukan studi kelayakan. Kedua, 


\section{Jurnal Ilmiah Ekonomi Islam, 6(03), 2020, 474}

menetapkan jenis usaha produktif. Ketiga, melakukan bimbingan dan penyuluhan. Keempat, melakukan pemantauan, pengendalian dan pengawasan. Keenam, melakukan evaluasi. Selanjutnya adalah membuat laporan.

Pendistribusian zakat kepada para mustahik dapat dalam bentuk konsumtif atau produktif. Zakat secara konsumtif diberikan kepada mustahik yang tidak memiliki kemampuan mengolah dana sehingga akan lebih bijaksana apabila diberikan berupa uang untuk keperluan sehari-hari. Sementara, zakat produktif diberikan kepada mustahik yang cukup mampu untuk mengelola modal yang diberikan. Pemberian dapat berupa uang, peralatan atau hewan ternak dengan tujuan dapat meningkatkan pendapatan para mustahik (Widiastuti, 2016). Dengan demikian, jumlah dana yang didistribusikan harus berbeda-beda

\section{Tabel 1}

Pendayagunaan Zakat di Lembaga Amil Zakat, Infak dan Shodaqoh Muhammadiyah (LAZISMU) Kabupaten Malang

\begin{tabular}{|c|c|c|c|}
\hline No & Uraian & Bentuk Pelaksanaan & $\begin{array}{l}\text { Penilaian } \\
\text { Efektifitas }\end{array}$ \\
\hline 1 & Kegunaan & $\begin{array}{l}\text { Kegunaan donasi zakat adalah untuk golongan penerima zakat, meliputi: [1] } \\
\text { orang-orang fakir, [2] orang-orang miskin, [3] amil zakat, [4] para mu'allaf } \\
\text { yang dibujuk hatinya, [5] orang-orang yang terlilit utang, [6] untuk jalan Allah } \\
\text { dan [7] untuk mereka yang sedang dalam perjalanan, sebagaimana tertulis } \\
\text { dalam QS. At Taubah: 60. Sementara untuk golongan budak tidak diberikan } \\
\text { penyaluran dana zakat bagi golongan ini. }\end{array}$ & $\checkmark$ \\
\hline 2 & $\begin{array}{l}\text { Ketepatan \& } \\
\text { Objektifitas }\end{array}$ & $\begin{array}{l}\text { Dilaksanakan survey dan fasilitas dana zakat muqayyad (terikat) -yaitu } \\
\text { penyaluran sesuai dengan keinginan donator (muzakki) }\end{array}$ & $\checkmark$ \\
\hline 3 & $\begin{array}{l}\text { Ruang } \\
\text { Lingkup }\end{array}$ & $\begin{array}{l}\text { Ruang lingkup zakat masih belum sepenuhnya efektif disebabkan karena } \\
\text { sedikitnya prosentase dana zakat yang terkumpul dibandingkan dengan } \\
\text { shodaqoh atau infak (prosentase 10-90\%); dan juga belum rutinnya donator di } \\
\text { LAZISMU Kabupaten Malang dalam menunaikan zakat. } \\
\text { Zakat produktif belum optimal dilaksanakan sebab problem Sumber Daya } \\
\text { Manusia (SDM). }\end{array}$ & $\checkmark$ \\
\hline 4 & $\begin{array}{l}\text { Efektifitas } \\
\text { Biaya }\end{array}$ & $\begin{array}{l}\text { Efektifitas biaya dilakukan dengan menyediakan fasilitas pembayaran } \\
\text { menggunakan transfer ke rekening LAZIMU dan juga fleksibilitas manajemen } \\
\text { pengumpulan dan penyaluran dana zakat berdasarkan cabang-cabang di } \\
\text { bawah Pengurus Daerah Muhammadiyah (PDM) Kabupaten Malang. } \\
\text { LAZISMU kabupaten Malang mendapatkan laporan dari kegiatan } \\
\text { pengumpulan dan penyaluran dana zakat tersebut. }\end{array}$ & $\checkmark$ \\
\hline 5 & $\begin{array}{l}\text { Ketepatan } \\
\text { Waktu }\end{array}$ & $\begin{array}{l}\text { Ketepatan waktu dalam penyaluran dana zakat terlaksana, sebab dana zakat } \\
\text { yang terkumpul disalurkan pada bulan setelahnya kepada golongan penerima } \\
\text { zakat. } \\
\text { Selanjutnya, dalam pelaporan dana zakat belum sepenuhnya tepat waktu sebab } \\
\text { membutuhkan waktu dua bulan setelah donator membayar dana zakat kepada } \\
\text { LAZISMU. }\end{array}$ & $\mathbf{X}$ \\
\hline
\end{tabular}

sesuai dengan tempat, waktu, jenis usaha, dan sifat penerima zakat. Untuk itu memanfaatkan serta mendayagunakan zakat memerlukan kebijaksanaan dan visi kemaslahatan dari pemerintah selaku amil zakat (Noor, 2003).

Berdasarkan pembahasan di atas, hasil dari penelitian ini selaras dengan penelitian yang dilakukan oleh Zakiyah (2006), Fajar (2016), Pratama (2013), Rusli, Hamzah \& Syahnur (2013) yang menyatakan bahwa zakat berperan begitu signifikan terhadap pemberdayaan ekonomi para mustahik zakat. Dalam pelaksanaan pendayagunaan zakat, guna peningkatan ekonomi mustahik, digunakan metode revolving fund sebagaimana penelitian yang dilakukan oleh Nafiah (2015). Hanya saja dalam pelaksanaannya terdapat kendala SDM dalam pendampingan dan evalusasi program. 


\begin{tabular}{|c|c|l|c|}
\hline No & Uraian & \multicolumn{1}{|c|}{ Bentuk Pelaksanaan } & \multicolumn{1}{|c|}{$\begin{array}{c}\text { Penilaian } \\
\text { Efektifitas }\end{array}$} \\
\hline 6 & Akuntabilitas & $\begin{array}{l}\text { Akuntabilitas dana zakat ditunjukkan dengan adanya standar pelaporan } \\
\text { keuangan PSAK 301, dan juga tata kelola organisasi dengan keberadaan } \\
\text { Dewan Pengawas dan audit internal. } \\
\text { Akuntabilitas dana zakat bagi donator adalah dengan adanya bukti } \\
\text { pembayaran (kwitansi) dan juga pelaporan dalam bentuk majalah 2 bulan } \\
\text { setelah pembayaran di lakukan. }\end{array}$ & $\checkmark$ \\
\hline
\end{tabular}

\section{KESIMPULAN}

Berdasarkan pembahasan yang dikemukakan, dapat disimpulkan bahwa pendayagunaan dana zakat di LAZISMU Kabupaten Malang mampu untuk meningkatkan pemberdayaan ekonomi mustahik, ditinjau dari aspek kegunaan, keakuratan dan obyektivitas, ruang lingkup program, efektivitas biaya, dan akuntabilitas pelaporan. Sementara pada ketepatan waktu, pelaporan keuangan dana zakat masih belum tepat waktu.

Keterbatasan dalam penelitian ini adalah objek pembahasan yang sempit, yaitu fokus penelitian hanya pada satu lembaga zakat, infak dan shodaqoh. Penelitian selanjutnya disarankan untuk melakukan penelitian perbandingan antara dua lembaga atau lebih.

\section{UCAPAN TERIMA KASIH}

Terima kasih kepada sebesa-besarnya diucapkan kepada Majelis Pendidikan Tinggi, Penelitian dan Pengembangan (Diktilitbang) PP Muhammadiyah atas Grant Penelitian RisetMu Tahun 2020 dalam memberikan support pendanaan penelitian ini sehingga penelitian dapat terlaksana dengan baik dan lancar.

\section{REFERENSI}

Abidah, A. (2010). Pengelolaan Zakat Oleh Negara Dan Swasta: Studi Efektifitas dan Efisiensi Pengelolaan Zakat Oleh BAZ Dan LAZ Kota Madiun. Kodifikasia, 4(1), 1-31. DOI: 10.21154/kodifikasia.v4i1.745

Al-Aa'ani, Khalid Abdur Razzaq (1999). Masharifu Az-zakat Wa Tamlikuha fi Dhaui Al-Kitab wa As-Sunnah. Oman. Dar Usamah li al-Nashr wa Tauzi'.

Al-Zuhayly, Mustafa (2007). Fiqih Islam Wa Adillatuhu. Juz III. Bairut. Daar al-Fikr. 17881789.
Amsari, S. (2019). Analisis Efektifitas Pendayagunaan Zakat Produktif Pada Pemberdayaan Mustahik (Studi Kasus LAZISMu Pusat). AGHNIYA: Jurnal Ekonomi Islam, 1(2). Retrieved from: http://jurnal.umsu.ac.id/index.php/AGHNIYA/ar $\underline{\text { ticle/view/3191 }}$

Beik, I. S. (2009). Analisis peran zakat dalam mengurangi kemiskinan: studi kasus Dompet Dhuafa Republika. Jurnal Pemikiran dan Gagasan, 2(1), 1-11. Retrieved From: https://www.researchgate.net/profile/Irfan_Beik/ publication/281207037_Analisis_Peran_Zakat_ dalam Mengurangi Kemiskinan_Studi_Kasus Dompet_Dhuafa_Republika/links/55db325508a ed6a199ac553e/Analisis-Peran-Zakat-dalamMengurangi-Kemiskinan-Studi-Kasus-DompetDhuafa-Republika.pdf

Burhan, Bungin. (2003). Analisis Data Penelitian Kualitatif. Jakarta: RajaGrafindo Persada.

Departemen Agama Republik Indonesia. (2007). AlQur'an dan Terjemahannya. Bandung. PT Syamil Cipta Media.

Dzikron Am, M., Nasrullah, R., \& Shofi M, D. (2005). Efektivitas organisasi zakat dalam pemberdayaan ekonomi. Retrieved from: http://repository.unisba.ac.id:8080/xmlui/bitstrea m/handle/123456789/9639/fulltext_dzikron_mi mbar_vol_xxi_no_3_2005_sv.PDF? sequence $=1$

Fajar, E. P. (2016). Efektivitas Pendayagunaan Zakat Produktif Pada Pemberdayaan Ekonomi Mustahik (Studi Kasus di Badan Amil Zakat Nasional/BAZNAS Kabupaten Banyumas) (Doctoral dissertation, IAIN Purwokerto). Retrieved from: http://repository.iainpurwokerto.ac.id/753/

Hafidhuddin, Didin. (2007). Agar Harta Berkah dan Bertambah. Jakarta. Gema Insani.

Hakim, R. (2020). Manajemen Zakat: Histori, Konsepsi, dan Implementasi. Jakarta. Prenada Media Group. 
Hakim, R. (2017). Dakwah Bil Hal: Implementasi Nilai Amanah dalam Organisasi Pengelola Zakat untuk Mengurangi Kesenjangan dan Kemiskinan. Iqtishodia: Jurnal Ekonomi Syariah, 2(2), 42-63. https://doi.org/10.35897/iqtishodia.v2i2.100

Hakim, R. (2018, April). Kotekstualisasi Fikih Golongan Penerima Zakat (Asnaf Tsamaniyah) Zakat Dan Relevansinya Dengan Penanggulangan Kemiskinan di Indonesian. In Proceedings of Annual Conference for Muslim Scholars (No. Series 1, pp. 393-406). Retrieved from

proceedings.kopertais4.or.id/index.php/ancoms/ article/view/143

Hakim, R., Sawarjuwono, T., \& Djalaluddin, A. (2018). Proposing the value of Amanah as the foundation of Zakah organizational culture. OPCION, 1(2), 35-41. Retrieved from http://scieloopcion.com/35-21/2.pdf

Hakim, R. (2020). Studi Komparatif Kriteria Amil Zakat, Hak dan Kewajibannya Pada Lembaga Amil Zakat Nasional (LAZNAS) Di Indonesia. ZISWAF: Jurnal Zakat dan Wakaf, 7(1), 1-15. http://dx.doi.org/10.21043/ziswaf.v7i1.6925

Handoko, T. Hani. (1991). Manajemen Edisi II. Yogyakarta. BPFE.

Karimah, A. (2017). Efektivitas pendayagunaan zakat produktif pada program pemberdayaan ekonomi masyarakat (Bachelor's thesis, Jakarta: Fakultas Ekonomi dan Bisnis UIN Syarif Hidayatullah Jakarta). Retrieved from: http://repository.uinjkt.ac.id/dspace/handle/1234 56789/40740

Kementerian Wakaf dan Urusan Keislaman Kuwait (1983). Al-Mausu'ah fiqhiyyah atau Ensiklopedia Fiqh Islam. Vol. 23. al-Kuwait. Penerbit Kementerian.

Kholiila, W. (2016). Analisis Efektivitas Program Pendayagunaan Dana Produktif ZIS Terhadap Pendapatan Mustahiq (Studi Kasus Dompet Dhuafa Republika) (Bachelor's thesis, Jakarta: Fakultas Ekonomi dan Bisnis UIN Syarif Hidayatullah Jakarta). Retrieved from: http://repository.uinjkt.ac.id/dspace/bitstream/12 3456789/33353/1/WILDA\%20KHOLIILAA.pdf

Maghfiroh, Mamluatul. (2007). Zakat, Yogyakarta. Pustaka Insan Madani.

Mashur, Kahar. Wawancara, 2019, Agustus 20, Pukul 09.00 WIB.
Mashur, Kahar. Wawancara, 2019, September 10, Pukul 10.00 WIB.

Mubarok, A., \& Fanani, B. (2014). Penghimpunan dana zakat nasional (Potensi, realisasi dan peran penting organisasi pengelola zakat). Permana, 5(2). Retrieved from: http://ejournal.upstegal.ac.id/index.php/per/article/view $\underline{1363}$

Muhammad. (2002). Zakat Profesi: Wacana Pemikiran dalam Fiqh Kontemporer. Jakarta. Salemba Diniyah.

Nafiah, L. (2015). Pengaruh Pendayagunaan Zakat Produktif Terhadap Kesejahteraan Mustahiq Pada Program Ternak Bergulir BAZNAS Kabupaten Gresik (Doctoral dissertation, UIN Sunan Ampel Surabaya). Retrieved from: jurnalfebi.uinsby.ac.id/index.php/elqist/article/d ownload/74/71

Nawawi, Ismail. (2010). Zakat Dalam Perspektif Fiqh, Sosial \& Ekonomi, Surabaya. PutraMedia Nusantara.

Nazir, Mohamad. (1998). Metode Penelitian. Jakarta: Ghalia Indonesia.

Ningrum, R. T. P. (2016). Penerapan Manajemen Zakat Dengan Sistem Revolving Fund Models Sebagai Upaya Efektifitas Penyaluran Zakat Produktif (Studi Pada Lembaga Manajemen Infaq Madiun). El-Wasathiya: Jurnal Studi Agama, 4(1), 1-21. Retrieved from http://ejournal.kopertais4.or.id/mataraman/index .php/washatiya/article/view/2347

Noor, Ruslan Abdul Ghofur. (2003). Konsep Distribusi Dalam Ekonomi Islam Dan Format Keadilan Ekonomi Di Indonesia. Yogyakarta. Pustaka Pelajar.

Permono, Sjechul Hadi. (1992). Pendayagunan Zakat Dalam Rangka Pembangunan Nasional. Jakarta. Pustaka Firdaus.

Pratama, E. A. (2013). “Optimalisasi Pengelolaan Zakat Sebagai Sarana Mencapai Kesejahteraan Sosial" (Sebuah Studi Di Badan Amil Zakat Kota Semarang), (Doctoral dissertation, Univarsitas Negeri Semarang). Retrieved from: https://lib.unnes.ac.id/17965/

Pratama, Y. C. (2015). Peran zakat dalam penanggulangan kemiskinan (Studi kasus: Program zakat produktif pada Badan Amil Zakat Nasional). Tauhidinomics, 1(1), 93-104. Retrieved from: http://journal.uinjkt.ac.id/index.php/tauhidinomi cs/article/view/3327 
Qadir, Abdurrachman. (2001). Zakat Dalam Dimensi Mahdah dan Sosial, ed. 1, cet. 2, (Jakarta: Raja Grafindo Persada.

Raco, J. (2003). Metode Penelitian Kualitatif: Jenis, Karakteristik, dan Keunggulannya. Jakarta: PT Grasindo.

Ridwan, Mas'ud Muhammad. (2005). Zakat dan Kemiskinan Instrumen Pemberdayaan Ekonomi Umat. Yogyakarta. UII Press.

Riyadi, A. (2014). Manajemen Pengelolaan Zakat Produktif dalam Perspektif Bank Islam. Iqtishadia: Jurnal Kajian Ekonomi dan Bisnis Islam STAIN Kudus, 7(2), 335-356. Retrieved from:

https://www.neliti.com/publications/91002/man ajemen-pengelolaan-zakat-produktif-dalamperspektif-bank-islam

Rusli, A. H., \& Syahnur, S. (2013). Analisis Dampak Pemberian Modal Zakat Produktif Terhadap Pengentasan Kemiskinan Di Kabupaten Aceh Utara. Jurnal Ilmu Ekonomi Pascasarjana Universitas Syiah Kuala, 1(1), 56-63.

Savid, A. N. (2018). "Efektivitas Pendayagunaan Zakat Produktif Dalam Pemberdayaan Ekonomi Mustahik (Studi Kasus Di Badan Amil Zakat Nasional Kabupaten Gresik)" (Dissertation, University of Muhammadiyah Malang). Retrieved from: http://eprints.umm.ac.id/40945/

Savid, A. N. (2017). Efektifitas Zakat Produktif dalam Pemberdayaan Ekonomi Mustahik: Studi Pendahuluan Pada Badan Amil Zakat (BAZ) Kabupaten Gresik. Falah: Jurnal Ekonomi Syariah, 2(1), 90-108. DOI: https://doi.org/10.22219/jes.v2i1.4361
Sugiyono. (2003). Metode Penelitian Kuantitatif, Kualitatif dan R\&D. Bandung: CV Alfabeta.

Sujarweni, V. Wiratna. (2014). Metode Penelitian; Lengkap, Praktis, dan Mudah Dipahami. Yogyakarta. Pustaka Baru Press.

Sumantri, R. (2017). Efektifitas dana zakat pada mustahik zakat community development sumatera selatan dengan pendekatan CIBEST. IECONOMICS: A Research Journal on Islamic Economics, 3(2), 209-234. DOI: https://doi.org/10.19109/ieconomics.v3i2.1688

Tim Emir (2016). Panduan Zakat Terlengkap. Jakarta. Emir.

Sumadi, S. (2017). Optimalisasi Potensi Dana Zakat, Infaq, Sadaqah Dalam Pemerataan Ekonomi Di Kabupaten Sukoharjo (Studi Kasus di Badan Amil Zakat Daerah Kab. Sukoharjo). Jurnal Ilmiah Ekonomi Islam, 3(01), 16-26.

Widiastuti, T. (2016). Model Pendayagunaan Zakat Produktif oleh Lembaga Zakat dalam Meningkatkan Pendapatan Mustahiq. Jurnal Ekonomi dan Bisnis Islam (JEBIS), 1(1), 89-102. DOI: http://dx.doi.org/10.20473/jebis.v1i1.1424

Witrido. (2010). "Efektifitas Produk Al Qardhul Hasan PT. BNI Syariah Cabang Pekanbaru Bagi Pengembangan Usaha Kecil di Kota Pekanbaru" (Skripsi) Jurusan Huum Ekonomi Syariah Universitas Islam Negeri Sultan Syarif Kasim RIAU, Pekanbaru. 